Cahiers $d u$ MONDE RUSSE

\section{Cahiers du monde russe}

Russie - Empire russe - Union soviétique et États indépendants

$58 / 4 \mid 2017$

Varia

\title{
Nick Baron, ed., Displaced Children in Russia and Eastern Europe, 1915-1953: Ideologies, Identities, Experiences
}

\section{Olga Kucherenko}

\section{(2) OpenEdition}

1 Journals

\section{Electronic version}

URL: http://journals.openedition.org/monderusse/10157

DOI: 10.4000/monderusse.10157

ISSN: $1777-5388$

\section{Publisher}

Éditions de l'EHESS

\section{Printed version}

Date of publication: 1 October 2017

Number of pages: 697-699

ISBN: 978-2-7132-2698-4

ISSN: $1252-6576$

\section{Electronic reference}

Olga Kucherenko, "Nick Baron, ed., Displaced Children in Russia and Eastern Europe, 1915-1953: Ideologies, Identities, Experiences", Cahiers du monde russe [Online], 58/4 | 2017, Online since 01 October 2017, connection on 06 January 2021. URL: http://journals.openedition.org/monderusse/ 10157 ; DOI: https://doi.org/10.4000/monderusse.10157 


$\begin{array}{cccccccccccccccccc}\mathrm{P} & \mathrm{E} & \mathrm{R} & \mathrm{I} & \mathrm{O} & \mathrm{D} & \mathrm{E} & & \mathrm{S} & \mathrm{O} & \mathrm{V} & \mathrm{I} & \mathrm{E} & \mathrm{T} & \mathrm{I} & \mathrm{Q} & \mathrm{U} & \mathrm{E} \\ \mathrm{E} & \mathrm{T} & & \mathrm{P} & \mathrm{O} & \mathrm{S} & \mathrm{T} & \mathrm{S} & \mathrm{O} & \mathrm{V} & \mathrm{I} & \mathrm{E} & \mathrm{T} & \mathrm{I} & \mathrm{Q} & \mathrm{U} & \mathrm{E}\end{array}$

Nick BARON, ed.

\section{Displaced Children in Russia and Eastern Europe, 1915-1953 Ideologies, Identities, Experiences}

Leiden - Boston : Brill, 2016, xv + 295 p.

Anyone who has ever participated in the production of an edited-let alone served as the editor of one-will be painfully aware of the difficulty of making all the chapters, written by different authors with diverse styles of narration and perspectives, stand out as a consistent and fluid entity. Nick Baron, the editor of Displaced Children in Russia and Eastern Europe, 1915-1953, is to be congratulated on putting together a well-integrated collection of papers and providing the field of childhood studies with a volume of significant value. Moreover, the book's main themes breach the confines of the narrow discipline and will be of interest to specialists in other theoretical and practical areas, from historians of modernizing societies, students of oral history and political scientists to child psychologists, social workers and humanitarian relief activists.

The book is an outcome of several collaborative research projects, involving an international team of scholars. Its main concentration is the memory of involuntary displacement effected by war, racial persecution, population transfers and social engineering. As its title suggests, the book roughly encompasses the most turbulent and torturous period of Europe's $20^{\text {th }}$ century history, marked by the collapse of old empires, the upsurge of aggressive nationalism and the rise of totalitarian regimes. This was the time when old and newly created states were preoccupied with ideas of social control, welfare and family policy, especially the regulation and cultivation of children. Nowhere else were these programmes applied with such "unprecedented scope and intensity" (3) as in Eastern Europe and the Soviet Union. Stumbling from one crisis into another, the region was a Petri dish for radical views on child socialization and often aggressive nationalisation of children, who were seen both as "national property," on whom the nation's survival depended, and as potential "forces of social dissolution" (8), who needed to be brought back into the fold, and their lost identities recovered or "reforged." Thus, the edited volume is essentially about the different ways modernizing states managed real and perceived challenges to social stability and national preservation, and how these policies evolved.

By elucidating normative notions of childhood and state interventions, the contributors to this volume reveal a great deal about morality and motives of adults in power. They also offer a glimpse into the realities of millions of children whose most significant formative years were fringed by two world wars. One of the main premises of the book is that the children should be viewed not only as victims and tools of social change, but as active and articulate social agents, capable of making sense of their predicament, devising strategies of coping and constructing their identities. As such, the contributors raise the question of the children's agency as 
well as evaluating official discourses of childhood. Adopting this double-edged approach of looking at the problem from the top and at the grassroots, the authors carefully (and critically) listen to the children's voices, be it their immediate perceptions or recollections of their older selves.

The case studies consider different forms of child displacement and replacement as both state practice and social experience. Aldis Purs and Elizabeth White examine life trajectories of refugee children from Latvia and Russia during the First World War. Drawing on a unique set of archival materials, they both examine children's experiences, how they remembered them and how adults tried to incorporate these children into the identity projects of their respective communities. While White shows that Russian children were perceived by rescue workers as the preserves of national tradition ruined by the Bolsheviks, Purs argues that the orphans "fitted awkwardly" into the myth of state-making. Those interested and familiar with the Soviet case will find the discussion of state and parental guardianship in interwar Latvia fascinating and warranting some revealing comparisons. Rachel Faircloth Green offers such an opportunity by examining the Soviet adoption law and attitude towards orphans in the immediate aftermath of World War II. According to Green, the state adopted an affirmative way of reintegration, promoting the equivalence of adoptive and biological families, but the children were rarely able to shake off the stigma of marginalisation. Not unlike in interwar Latvia, war orphans in the post-war Soviet Union had a hard time re-integrating and never became "a focal point of popular identification or sympathy" (66) beyond the propaganda image of war-induced suffering. Re-integration of orphans and the children abducted by the Nazis into their national communities was a high priority for relief workers in Eastern Europe around the same time. Yet, echoing many themes addressed by White, Tara Zahra reveals that these organisations adopted nationalist rhetoric pertaining to displaced children whom they tried to "renationalise" through repatriation, sometimes despite the children's wishes. Thus, in their eagerness to "act in the best interest of the child," these organizations violated the human rights of some of the children. This belief that youngsters could not grow into healthy and productive individuals without a stable sense of national identity, also governed the Soviet hosts of young Spanish refugees fleeing the civil war in their home country. The Soviets, however, also sought to fine-tune that identity. As Karl Qualls argues, when the Soviet state assumed the parental responsibility of care and development of these children, it attempted to create "Soviet-Spanish hybrids." (132) Yet in the process of making the children Spanish in form but socialist in nature, Soviet pedagogues also excised some basic aspects of the niños' cultural identity, such as their religious beliefs. When it came to altering the identity of the children of "kulaks" and perceived enemies of the Soviet state from the Baltics, the authorities assumed a very uncompromising stance. The chapters by Michael Kaznelson and Nick Baron as well as Tomas Balkelis examine the experience of children deported by the Soviet state to special settlements. The authors focus on how these children survived the trauma of exile, the annihilation of their entire families, and the misery of state institutions; how this experience affected their 
sense of self, of their homeland and ethnicity/origin; and how they incorporated the memory of forced displacement into the fabric of their adult lives. As is clearly shown in several chapters, what these children had lived through was important not only to them, but also to the grown-ups seeking to preserve and use the youngsters' memories in the rebuilding or construction of a positive national identity. However, looking at the child survivors of the Holocaust and how their memory was studied and represented by Polish Jewish intellectuals, Gabriel Finder finds that there was a danger that their voices would be dimmed by those of the adult architects of such identity for the surviving communities.

Therefore, all the chapters in their own way engage with questions of trauma, agency, memory, identity and subjectivity. Despite diverse sources, approaches and perspectives their authors engage with similar thematic, conceptual and methodological concerns as they study children as "both socially-situated objects and self-aware subjects." (3) The wealth of original material and fascinating background information will offer students of childhood, migration and modernization an invaluable resource and guidance for new research and analyses.

It is regrettable that the geographic scope of the book does not include other countries of Eastern Europe, but mostly covers the Soviet Union, the Baltic states and Poland. The editor, however, makes a strong case for the former Russian imperial domains in his extensive introductory section, exhibiting a superb command of the secondary literature and providing copious references to studies of childhood in other countries of Eastern and Central Europe. Let's hope Displaced Children in Russia and Eastern Europe gets the very positive reception it deserves.

\section{Olga Kucherenko}

Cambridge University 